\title{
Ethics treaty to target genome implications
}

Paris. Prospects for reaching a consensus on an international agreement on bioethics came a step closer last week with the second meeting of the United Nations Educational Scientific and Cultural Organisation's (UNESCO's) International Bioethics Committee (IBC) in Paris.

The organization is expected to approve a declaration on 'the protection of the human genome' in 1998, and to follow it up with a treaty that would be binding on its signatories. The declaration would be modelled on the 1948 Universal Declaration of Human Rights, and the committee hopes to give it a long shelf- life by avoiding "dogma" and remaining "open to scientific progress", says its chairwoman, Noëlle Lenoir.

The unexpected degree of consensus stems largely from the committee's decision to concentrate on issues raised by genome research, rather than more controversial issues such as patents or therapeutic abortion. The principles of human dignity, of free and informed consent, and of the confidentiality of genetic data that can be traced back to an individual, make up the proposed declaration's backbone.

Indeed, 'genetic reductionism' - the tendency to "stigmatize, ostracize or eliminate" individuals or groups not meeting a genetic norm - emerged as the biggest threat from genome research during the threeday debate. "We must make sure that the folly of genetic purity does not replace the folly of racial purity", says Lenoir.

According to the International League of Societies for Mentally Handicapped Persons, for example, "invisible" social, legal and financial pressures are already forcing women to abort disabled fetuses. Genome research, it warned the committee, could "geneticize social policy", and erode public support for disability healthcare.

The state's duty to support those genetically at risk from illness or handicap is emphasized in the proposed UNESCO declaration, which adds that individuals cannot be "reduced to their genetic characteristics" or be discriminated against because of them.

A second message of the meeting was that too much attention has been paid to the

\section{French ministers face poisoning charges}

Paris. Formal charges of "collusion in poisoning" are expected to be made this week against Laurent Fabius, the former Socialist prime minister, and two of his cabinet colleagues - Edmond Hervé and Georgina Dufoix - over their role in France's HIV-contaminated blood scandal in the mid-1980s. The charge carries a maximum sentence of 30 years in prison.

Many scientists and physicians remain convinced that the two physicians already convicted in a magistrate's court on the benefits", she says. sues "for no good end", concludes a preliminary report on gene therapy drawn up by one working group.

Many bioethicists, it argues, have mistakenly assumed that somatic gene therapy is about treating genetic diseases. But its main use will be to treat common diseases: cells might be genetically engineered to provide protection against the side-effects against HIV. in the same way. surgery. asks the report. clearly established". negative aspects of genetics research. "The heat has to be taken out of the bioethics debate," says Lenoir. Bioethics itself has to switch from a "defensive approach" to a "balanced outlook that considers risks and

Indeed, some favourite bioethical arguments took a hammering at the meeting. Excessive discussion of "notional" gene therapy has been a "mistake", arousing popular fears and misjudgements of present is-

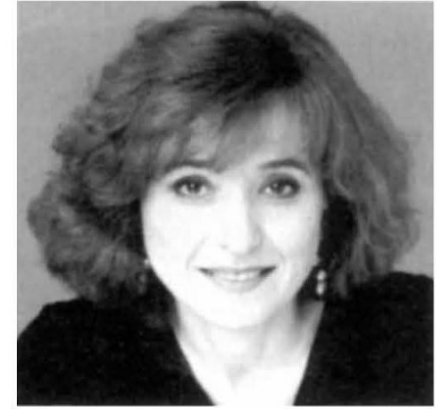

Lenoir: 'we must avoid the folly of genetic purity'.
It also says that debates about germline gene therapy, and 'directed evolution', amount to much ado about nothing. The only application envisaged, namely to spare descendants a serious disease, could ultimately be achieved more cheaply by sorting sperm, or by selecting embryos (as is already done in several countries).

Developing expensive germline therapy for individuals who disapprove of abortion or selective implantation, or who are unable to produce disease-free embryos, is not a public policy option, says the report, primarily because of the expense. But banning the technique is premature and unnecessary, as a valid need might arise.

The report of another working group presented to the committee claims that the focus of genetic screening is also shifting from genetic to common diseases. By the end of of treatments such as cancer therapy, or

The real risk of somatic gene therapy, it asserts, is that medical enthusiasm may override human rights during its experimental phase. But once the technique becomes commonplace, it will be no more dangerous than any other therapy, and should be regulated

The report also argues that somatic gene therapy for 'enhancements' should not be dismissed as unethical. Medical progress leads to the redefinition of many conditions - such as memory loss with age - as 'diseases', it says, while somatic cell enhancement is no different from cosmetic

Similarly, the working group's report says that although germline gene therapy should be banned for enhancement purposes, it should not be banned for therapeutic uses. "If it is morally acceptable to cure a condition by somatic gene therapy, then why not to eliminate it by the germline?"

misdemeanour of distributing factor VIII contaminated with HIV in 1985 , did not receive fair trials. But both physicians, and one other, now also face the charge of poisoning (see Nature 370,$404 ; 1994$ ).

Some feel that this criminal trial, along with that of the three politicians, may finally provide an unequivocal explanation of the events of 1985 . Fabius has said that he wishes that "the judiciary will accomplish its mission so that the truth be

D. B. the decade, genetic factors will be found for around one-quarter of cancers and heart diseases, says David Shapiro, the group's rapporteur and executive secretary of the UK's Nuffield Council of Bioethics.

One implication, says Shapiro, is that the proposed declaration should consider ignoring the contentious issue of therapeutic abortions for serious genetic disorders, as these will in future represent an increasingly small proportion of screenings.

At the same time, genetic testing will increasingly yield information about an individual's predisposition to multigenic or multifactorial conditions. Screening should therefore be restricted to serious disorders, in particular those that strike before adulthood, says the report, while screening for late-onset diseases should be done with "great care". The greater the availability of treatment, the better the case for screening.

Screening should also be voluntary, says Shapiro, and genetic information should in general remain confidential. Abortion should be banned, he says, for cosmetic reasons, or to avoid normal traits (such as less than average size) or a predisposition to treatable diseases.

Despite a growing consensus about the content of the proposed declaration, there was wide concern among those attending the Paris meeting that a lack of precision in its wording could reduce its effectiveness.

But Lenoir, who is a lawyer, argues that such "constructive ambiguity" is needed to ensure the flexibility that will get consensus. The value of international law, she says, is that it provides a reference for national legislators, and a last resort to which victims can appeal.

Declan Butler 